[Esai]

\title{
Keadilan Inter-generasi, Malapetaka Lingkungan, dan Pemuda di Era Antroposen
}

\author{
Rini Astuti \\ National University of Singapore
}

Antroposen adalah terminologi yang diperkenalkan oleh Paul Crutzen (2006) untuk mendefinisikan zaman geologis baru dimana aktivitas manusia telah secara fundamental memberikan dampak terhadap lingkungan global dan mendestabilisasi bumi secara permanen. Para pakar mengukur dampak aktivitas manusia terhadap malapetaka global misalnya melalui pengukuran hilangnya tutupan hutan tropis, bocornya lapisan ozon, hilangnya keanekaragaman hayati, kebakaran hutan dan lahan, menumpuknya limbah plastik, dan naiknya emisi gas rumah kaca. Kerusakan lingkungan ini menunjukkan pengaruh kuat aktivitas manusia terhadap alam, yang disebut oleh pakar sebagai perubahan antropogenik. Sains ini belum konklusif, dengan penelitian yang terus berlangsung untuk memeriksa apakah perubahan pada sistem bumi memiliki skala yang cukup untuk membenarkan deklarasi zaman baru. Namun demikian, gagasan Antroposen telah terbukti populer di kalangan pakar lingkungan dan, sampai batas tertentu, menyediakan kerangka untuk memikirkan kembali hubungan manusia dengan lingkungan (McGregor 2017). Esai ini menilik hubungan antara pemuda dengan malapetaka lingkungan global di era Antroposen. Namun, alih-alih melihat pemuda dan anakanak hanya sebagai korban, esai ini menitikberatkan pada peran pemuda dan anak-anak dalam menghadapi malapetaka lingkungan.

Perserikatan Bangsa-Bangsa mendefinisikan pemuda sebagai mereka yang berusia antara 15 dan 24 tahun (UNDESA 2018). Pemuda membentuk $17 \%$ dari populasi dunia yang pada tahun 2015 diperkirakan mencapai 1,2 miliar jiwa dan $87 \%$ tinggal di negara-negara berkembang.

Selain pemuda, terdapat 2,3 miliar anak di seluruh dunia, dan mereka adalah golongan yang paling rentan terhadap malapetaka lingkungan global seperti perubahan iklim karena berbagai faktor unik fisiologi dan psikologi anak (Stanberry et al. 2018). UNICEF (2015) mengeluarkan laporan yang memetakan lebih dari 1,45 miliar anak-anak yang diproyeksikan akan terdampak oleh kenaikan suhu global sebesar 2 derajat celsius. Dalam laporan lainnya, UNICEF (2019) menyoroti kerentanan 19 juta anak-anak di Bangladesh. Bencana ekstrim dan dampak perubahan iklim jangka panjang menempatkan anak-anak di Bangladesh ke dalam kemiskinan dan memaksa mereka untuk menjadi pengungsi. Di Asia Tenggara, seperti di Singapura, Malaysia dan Indonesia, balita dan anak-anak berisiko mengalami dampak kesehatan jangka panjang ketika menghirup partikel polutan mikro yang terkandung dalam kabut asap dari kebakaran hutan (Koplitz et al. 2016).

Situasi ini membuat kita berpikir soal keadilan inter-generasi yang menempatkan pemuda atau generasi mendatang sebagai pihak yang tidak hanya menerima dampak terberat malapetaka lingkungan, akan tetapi juga sebagai pihak yang memiliki solusi, agensi, dan pengetahuan untuk mengubah cara manusia berelasi dengan lingkungan. Konsep keadilan inter-generasi berangkat dari pemikiran bahwa generasi 
saat ini berutang pada generasi mendatang berupa kewajiban untuk menjaga sumber daya alam dan lingkungan. Barry (1997) mengatakan bahwa keuntungan yang timbul dari konsumsi sumber daya alam yang tidak dapat diperbarui, seperti minyak bumi dan batu bara, harus dikonsumsi dengan cara yang menjamin generasi mendatang masih dapat menikmati keuntungan yang sama. Barry (1997) juga menegaskan bahwa generasi mendatang tidak bisa dibebani dengan risiko dan dampak buruk sehubungan dengan efek samping dari pemakaian sumber daya yang dilakukan oleh generasi sekarang.

Ilmuwan sosial membahas lebih mendalam persoalan pembagian risiko dan keuntungan ini melalui konsep keadilan distributif (Walker 2012). Dalam debat mengenai keadilan distributif, ilmuwan mengingatkan bahwa konsep mengenai risiko dan keuntungan akan sangat relatif tergantung pada cara masyarakat di tempat tertentu mendefinisikan dan mengasosiasikannya. Bisa jadi apa yang dimengerti sebagai keuntungan oleh sebuah kelompok masyarakat tertentu akan menjadi risiko untuk kelompok masyarakat yang lain (Walker 2012). Lebih lanjut, Bell et al (2004) menyebutkan mengenai pentingnya prinsip kesetaraan dalam keadilan distributif. Bell dan rekannya menjelaskan bahwa prinsip kesetaraan merupakan prinsip umum yang selalu dipakai oleh advokat untuk mengukur pencapaian keadilan distributif. Diskusi mengenai prinsip kesetaraan mengingatkan pada konsep kerentanan yang menggarisbawahi bahwa setiap orang akan mengalami dampak yang berbeda ketika terpapar pada kerusakan lingkungan tergantung pada situasi sosial, ekonomi, ras, gender, dan geografis mereka (Cutter et al 2000). Konsep keadilan distributif penting untuk mendiskusikan keterkaitan antara pemuda dan malapetaka lingkungan global.

Konsep lain yang penting dalam membahas pemuda dan perubahan iklim adalah keadilan prosedural yang membahas keterlibatan generasi muda dan anak-anak dalam proses pengambilan keputusan. Proses pen- gambilan keputusan terkait dengan isu-isu pembangunan seringkali memarjinalkan keterlibatan mendalam generasi muda. Padahal generasi muda inilah yang akan menerima dampak terburuk dan risiko kerusakan lingkungan paling besar pada masa yang akan datang. Berangkat dari konsep keadilan lingkungan inter-generasi di atas yang mencakup keadilan distributif dan prosedural, esai ini akan membahas dua hal yang terkait dengan pemuda dalam era Antroposen yaitu peran pemuda dan anak dalam pembelajaran inter-generasi dan partisipasi mere$\mathrm{ka}$ dalam forum pembangunan internasional.

\section{AGENSI: PEMUDA DAN ANAK SEBAGAI SUMBER PENGETAHUAN MENGENAI PERUBAHAN IKLIM BAGI ORANG TUA}

Dewasa ini anak-anak dan pemuda tumbuh di dunia yang dipengaruhi globalisasi, sistem ekonomi politik neoliberal, konsumerisme, dan perubahan iklim. Mereka dihadapkan dengan momok perang global atas sumber daya, dan oleh pengalaman ekstrim misalnya bencana alam dan terorisme. Bersamaan dengan itu mereka dibenturkan dengan sistemsistem nilai yang berbeda misalnya dari media sosial yang menawarkan gratifikasi instan dan keterpaparan pada paham radikal. Oleh karena itu, pemuda dan anak biasanya memiliki fitur zaman yang dibentuk oleh semua pengalaman terkait keluarga, teman, lingkungan, sekolah, dan komunitas baik di dunia nyata maupun daring. Melalui media sosial, global dapat membentuk lokal, tetapi melalui relasi langsung dengan lingkungan itulah kekhasan kehidupan sosial dibangun dan diwujudkan. Inilah sebabnya mengapa respons terhadap malapetaka lingkungan global akan bervariasi di antara kaum muda dan anak-anak serta akan mengambil banyak bentuk budaya yang berbeda pula. Pendidikan tentang lingkungan, khususnya tentang perubahan iklim bagi kaum muda dan anak-anak, diperlukan untuk meningkatkan kapasitas mereka untuk mengatasi masalah lingkungan dan perkembangan yang terkait 
dengan perubahan iklim. Sebagian besar penelitian mengenai pendidikan inter-generasi telah menyoroti bagaimana generasi yang lebih tua memengaruhi pengetahuan, sikap, dan perilaku generasi muda. Namun, penelitian baru menunjukkan bahwa generasi yang lebih muda dapat memengaruhi pendekatan orang tua mereka terhadap berbagai topik kontroversial termasuk mengenai perubahan iklim (Lawson et al 2018).

Berdasarkan penelitian, orang dewasa ternyata lebih rentan terhadap pemikiran yang mengaburkan penilaian mereka ketika membentuk persepsi pada subjek yang kontroversial (Kollmuss and Agyeman 2002). Untungnya, anak-anak mampu memberikan peran aktif menyediakan pembelajaran inter-generasi kepada orang tua mereka untuk bisa lebih menerima isu-isu yang dianggap sulit atau kontroversial. Misalnya, anak-anak mampu mengubah pola konsumsi dan belanja orang tua ketika mereka berbelanja bersama (Calderon et al 2017). Contoh lain adalah penelitian mengenai anak-anak yang mampu berdiskusi secara kritis dan mengubah pandangan orang tua tentang orientasi seksual menjadi lebih toleran dan inklusif (LaSala 2000). Hal ini terjadi ketika anak-anak diberikan edukasi khusus yang memang menarget pembelajaran antar-generasi, sehingga terjadi transfer pengetahuan, sikap, dan perilaku kepada orang dewasa. Peneliti telah membuktikan efektifitas pembelajaran inter-generasi ini dalam perilaku konservasi energi (Boudet et al 2016), konservasi lingkungan (Leeming et al. 1997) dan persoalan banjir (Williams et al 2017). Singkatnya, jelas bahwa pembelajaran inter-generasi anak-ke-dewasa adalah mungkin, dan memberikan jalan yang efektif untuk perubahan lingkungan yang lebih baik dan pengurangan risiko perubahan iklim yang melibatkan generasi muda dan tua.

Lawson et al (2018) menjelaskan bahwa pembelajaran inter-generasi bukan hanya merupakan metode yang terbukti untuk menjangkau generasi yang lebih tua, tetapi juga efektif untuk topik yang penuh ideologis seperti perubahan iklim karena dua alasan. Pertama, anak-anak tampaknya lebih mampu mengu- raikan fakta ilmiah dari konteks politik daripada orang dewasa. Di antara orang dewasa, ideologi politik dan perspektif tentang sistem ekonomi politik dunia adalah pendorong utama polarisasi di sekitar diskusi mengenai perubahan iklim (McCright and Dunlap 2011). Namun, pada anak-anak yang memiliki tingkat pengetahuan perubahan iklim yang tinggi, mereka cenderung mencapai konsensus tentang perubahan iklim antropogenik (perubahan iklim yang disebabkan manusia), terlepas dari perspektif mereka mengenai sistem ekonomi politik dunia. Lebih jauh, penerimaan anak-anak terhadap perubahan iklim antropogenik tampaknya mampu menghadapi penyangkalan dari orang dewasa dalam kehidupan mereka. Misalnya, keyakinan guru tentang sifat antropogenik pemanasan global tidak memiliki hubungan dengan pandangan yang sama dari siswa mereka (Stevenson et al 2016). Hal serupa juga diamati dalam interaksi antara anak dan orang tua. Keyakinan anakanak terhadap perubahan iklim antropogenik tidak dipengaruhi oleh ketidakyakinan orang tua mereka terhadap pandangan yang sama.

Para ilmuwan mencatat beberapa prinsip utama yang bisa dipakai untuk memandu upaya mempromosikan pembelajaran inter-generasi anak ke dewasa dalam persoalan perubahan iklim (Lawson et al 2018). Upaya pendidikan semestinya difokuskan pada isu-isu lokal, dilakukan dalam jangka yang panjang dan melibatkan partisipasi aktif orang tua. Ballantyne et al (2001) menemukan dalam risetnya bahwa mendiskusikan persoalan lingkungan yang nyata yang dihadapi oleh suku Aborigin di Australia mampu mempromosikan sistem pembelajaran inter-generasi antara anak dan orang tua di dalam komunitas Aborigin. Membingkai perubahan iklim dalam skenario lokal meningkatkan penerimaan orang tua terhadap isu tersebut. Dalam riset yang lain, dimasukkannya komponen pekerjaan rumah yang mendorong keterlibatan orang tua (misalnya, dengan mewawancarai orang tua) merupakan kunci untuk menjembatani dialog pembelajaran inter-generasi an169 
tara anak dan orang dewasa (Leeming et al 1997; Williams et al 2017).

Pada era Antroposen, membangun sistem pembelajaran inter-generasi antara anak dan orang dewasa mengenai perubahan iklim antropogenik akan membangun cara hidup berdampingan dengan alam yang lebih berkelanjutan. Untuk mewujudkan hal ini diperlukan pemahaman bahwa anak dan pemuda adalah entitas yang memiliki pengetahuan dan kreativitas sehingga bisa menjadi kolega belajar setara orang dewasa.

\section{PARTISIPASI: KETERLIBATAN PEMUDA DALAM PENGAMBILAN KEPUTUSAN}

Greta Thunberg adalah remaja perempuan dari Swedia yang menjadi wajah gerakan advokasi anak muda dunia untuk perubahan iklim. Greta memulai aksinya pada saat libur musim panas dengan melakukan demo di depan kantor parlemen selama tiga minggu. Greta menginspirasi sekitar 1.6 - 2 juta anak muda di lebih dari 125 negara untuk melakukan aksi masa pada tanggal 15 Maret 2019 (Future Thinking 2019). Anak-anak dan pemuda seringkali merupakan kelompok masyarakat yang dipinggirkan dalam pengambilan keputusan terkait dengan sistem pembangunan dan ekonomi politik yang berakibat pada memburuknya lingkungan, walaupun mereka yang akan mengalami dampaknya di kemudian hari. Para peneliti yang mendalami konsep keadilan lingkungan inter-generasi berargumen bahwa hal ini termasuk dalam salah satu bentuk ketidakadilan prosedural (Walker 2012).

Schlosberg (2007) mengajukan argumen bahwa proses pengambilan keputusan yang inklusif dan demokratis adalah prakondisi untuk tercapainya keadilan prosedural. Literatur yang membahas konflik sumber daya alam biasanya menganalisis adanya ketidakadilan prosedural serta hilangnya kesempatan bagi pihak yang terkena dampak untuk didengar dan diperhatikan. Lebih lanjut, Schlosberg (2007) beranggapan bahwa negara dan pemer- intah memiliki peran penting dalam memastikan tercapainya keadilan prosedural melalui perangkat kebijakan dan aturan yang menjamin hak-hak warga negara. Akan tetapi, semakin tingginya peran sektor swasta dalam pengelolaan sumber daya alam yang bersifat neoliberal tentu saja mempengaruhi bagaimana keadilan prosedural ini dicapai. Untuk mencapai keadilan prosedural ada beberapa elemen kunci yang harus ada, yaitu: pihak-pihak yang terlibat dalam pengambilan keputusan harus memiliki akses terhadap informasi yang setara, pengambilan keputusan dilakukan tanpa paksaan, adanya mekanisme legal yang terbuka bagi pihak-pihak yang ingin menggugat hasil keputusan, serta adanya mekanisme yang memastikan keterlibatan kelompok-kelompok rentan dan marjinal (Scholsberg 2007; Walker 2012; Bickerstaff and Walker 2005).

Suara pemuda telah menjadi syarat hal yang harus didengar dan dimasukkan dalam proses pengambilan keputusan terkait pembangunan global (Yunita et al 2018). Hal ini dibahas pertama kali pada KTT Rio yang secara khusus menengarai kecenderungan pengabaian suara pemuda dalam pengambilan keputusan terkait lingkungan dan pembangunan pada tingkat nasional dan global. Pasca-KTT Rio, kedudukan pemuda sebagai agen perubahan dan entitas yang memiliki kreativitas semakin diperhatikan dalam proses pengambilan keputusan di Perserikatan Bangsa-Bangsa. Dalam berbagai forum internasional delegasi pemuda selalu diundang berpartisipasi seperti misalnya dalam pelaksanaan: Konvensi Kerangka Kerja Perserikatan Bangsa-Bangsa tentang Perubahan Iklim (UNFCCC), Konvensi Keanekaragaman Hayati (CBD), dan Forum Perserikatan Bangsa-Bangsa tentang Hutan (UNFF) (Yunita et al 2018).

Keterlibatan dan partisipasi generasi muda dalam inisiatif p0embangunan global dan proses pengambilan keputusan semakin menjadi urgensi yang tidak terbantahkan (Yunita et al 2018). Seruan yang berkembang untuk partisipasi pemuda umumnya dijelaskan dari sudut 
pandang etika dan keadilan. Remaja adalah pewaris masa depan dan target utama pembangunan. Oleh karena alasan ini, mereka harus diberi kesempatan untuk berbicara tentang isu-isu pembangunan yang mempengaruhi kehidupan dan masa depan mereka, serta tentang kebutuhan dan prioritas mereka. Keputusan yang dibuat tentang masa depan mereka akan hidup tidak boleh dibuat tanpa melibatkan mereka (Walker 2012). Selain itu, kaum muda dianggap memiliki potensi dan kapasitas yang besar untuk berkontribusi secara berarti bagi pembangunan berkelanjutan (Faulkner 2009). Inovasi dan kreativitas mereka, ketika dipelihara dan dikembangkan dengan baik, merupakan potensi untuk memajukan tujuan-tujuan pembangunan global utama (Yunita et al 2018).

Meskipun demikian, para peneliti melihat adanya indikasi bahwa mekanisme partisipatif yang disediakan untuk delegasi pemuda dalam forum internasional tidak memungkinkan kontribusi yang mendalam (Yunita et al 2018). Dengan demikian, partisipasi emansipatoris harus dilihat pada konteks yang lebih luas dari struktur kekuatan sosial-politik yang ada (Yunita et al 2018). Menurut Yunita et al (2018) prosedur pengambilan keputusan untuk masalah sosial tertentu sering kali bias orang dewasa. Menurut para ilmuwan ini ada sejumlah persyaratan yang diperlukan untuk mendukung partisipasi pemuda yang mendalam, yaitu: kerangka hukum; penyediaan informasi; perubahan budaya dan sikap di antara orang dewasa dan pembuat keputusan; mekanisme, layanan atau proses organisasi yang jelas dan mendukung; dan peluang untuk pengaduan ketika hak pemuda untuk berpartisipasi tidak dipenuhi. Menempatkan pemuda dan anak sebagai salah satu aktor penting dalam pengambilan keputusan terkait lingkungan dan agenda pembangunan internasional merupakan konsekuensi etis yang harus dilakukan di era Antroposen. Kesejahteraan ekologis mereka di masa depan dipengaruhi oleh berbagai keputusan politik yang dihasilkan dalam forum-forum global. Sehingga memastikan keterlibatan aktif dan mendalam anak-anak dan generasi muda dalam pengambilan keputusan merupakan bentuk keadilan inter-generasi yang mutlak harus dipenuhi.

\section{KESIMPULAN}

Bencana banjir, kebakaran hutan dan kekeringan di berbagai tempat memberikan visi yang mengerikan tentang apa yang akan terjadi di masa depan bagi banyak orang di seluruh dunia ketika suhu naik dan iklim mengubah lanskap lokaldan kehidupan masyarakat secara radikal. Semua ini memiliki implikasi yang akan membentuk bagaimana kita berelasi dengan generasi muda dan anak-anak kita. Adalah kaum muda yang harus berada di garis depan dari transformasi yang dibutuhkan, karena mereka pasti memiliki yang paling diharapkan dan pada akhirnya yang paling kalah, jika bersama-sama kita tidak dapat mengubah apa yang ada di depan. Pada era Antroposen ini kita mesti menciptakan gerakan-gerakan kolektif untuk masa depan yang lebih berkelanjutan, alih-alih bersifat eksploitatif terhadap manusia lain, lingkungan dan hewan. Kolektivitas bersama antara generasi muda dan tua adalah penyeimbang yang diperlukan untuk melawan kekuatan yang semakin menarik kita ke kelangkaan sumber daya, malapetaka lingkungan, dan ekosida. Melihat ke depan dan bertindak secara refleksif perlu menjadi bagian rutin bagaimana kita memeriksa struktur sosial, sistem, dan relasi antara yang muda dan yang tua saat ini. Malapetaka lingkungan global adalah masalah krusial di zaman sekarang dan ini adalah masalah yang harus dipecahkan bersama antara yang muda dan yang tua.

Catatan:

Rini Astuti menerima hibah penelitian dari Dewan Penelitian Ilmu Sosial Singapura (Social Science Research Council Singapore) untuk melakukan riset mengenai tata kelola lingkungan di Asia Tenggara, kode hibah MOE2016-SSRTG-068. 


\section{DAFTAR PUSTAKA}

Ballantyne, R., Fien, J., Packer, J. 2001. "Intergenerational Influence in Environmental Education: A Quantitative Analysis". Australian Journal of Environmental Education 17, 1-7. https://doi.org/10.1017/ S0814062600002378.

Barry, B. 1997. "Sustainability and Intergenerational Justice". Theoria: A Journal of Social and Political Theory 43-64.

Bell, B.S., Ryan, A.M., Wiechmann, D. 2004. "Justice Expectations and Applicant Perceptions". International Journal of Selection and Assessment 12, 24-38. https://doi.org/10.1111/ j.0965-075X.2004.00261.x.

Bickerstaff, K., Walker, G. 2005. "Shared Visions, Unholy Alliances: Power, Governance and Deliberative Processes in Local Transport Planning". Urban Studies 42, 2123-2144. https:// doi.org/10.1080/00420980500332098.

Boudet, H., Ardoin, N.M., Flora, J., Armel, K.C., Desai, M., Robinson, T.N. 2016. "Effects of a behaviour change intervention for Girl Scouts on child and parent energy-saving behaviours". Nat Energy 1, 16091. https://doi.org/10.1038/ nenergy.2016.91.

Calderon, J., Ayala, G.X., Elder, J.P., Belch, G.E., Castro, I.A., Weibel, N., Pickrel, J. 2017. "What Happens When Parents and Children Go Grocery Shopping? An Observational Study of Latino Dyads in Southern California, USA". Health Educ Behav 44, 5-12. https:// doi.org/10.1177/1090198116637602.

Crutzen, P.J. 2006. The "Anthropocene,"” in: Ehlers, E., Krafft, T. (Eds.), "Earth System Science in the Anthropocene". Springer Berlin Heidelberg, Berlin, Heidelberg; pp. 13-18. https://doi.org/10.1007/3-540-26590-2_3.
Cutter, S.L., Mitchell, J.T., Scott, M.S. 2000. "Revealing the Vulnerability of People and Places: A Case Study of Georgetown County, South Carolina". Annals of the Association of American Geographers 90, 713-737. https:// doi.org/10.1111/0004-5608.00219.

Editorial. 2019. "Future thinking". Nat. Clim. Chang. 9, 341-341. https://doi.org/10.1038/ s41558-019-0477-x.

Faulkner, K.M. 2009. "Presentation and Representation: Youth participation in ongoing public decision-making projects". Childhood 16, 89-104. https://doi. org/10.1177/0907568208101692.

Kollmuss, A., Agyeman, J. 2002. "Mind the Gap: Why do people act environmentally and what are the barriers to pro-environmental behavior?" Environmental Education Research 8, 239-260. https:/doi. org/10.1080/13504620220145401.

LaSala, M.C., 2000. "Lesbians, Gay Men, and Their Parents: Family Therapy for the Coming-Out Crisis*". Family Process 39, 67-81. https://doi.org/10.1111/j.15455300.2000.39108.x.

Lawson, D.F., Stevenson, K.T., Peterson, M.N., Carrier, S.J., Strnad, R., Seekamp, E. 2018. "Intergenerational learning: Are children key in spurring climate action?" Global Environmental Change 53, 204-208. https://doi. org/10.1016/j.gloenvcha.2018.10.002.

Leeming, F.C., Porter, B.E., Dwyer, W.O., Cobern, M.K., Oliver, D.P. 1997. "Effects of Participation in Class Activities on Children's Environmental Attitudes and Knowledge". The Journal of Environmental Education 28, 33 42. https://doi.org/10.1080/00958964.1997 .9942821 . 
McCright, A.M., Dunlap, R.E. 2011. "The Politicization of Climate Change and Polarization in the American Public's Views of Global Warming, 2001-2010". The Sociological Quarterly 52, 155-194. https://doi. org/10.1111/j.1533-8525.2011.01198.x.

McGregor, A., 2017. "Critical development studies in the Anthropocene". Geographical Research 55, 350-354. https://doi.org/10.1111/17455871.12206 .

Schlosberg, D. 2007. Defining Environmental Justice: Theories, Movements, and Nature: Theories, Movements, and Nature. USA: OUP Oxford.

Schlosberg, D. 2004. "Reconceiving Environmental Justice: Global Movements And Political Theories". Environmental Politics 13, 517 540. https://doi.org/10.1080/09644010420 00229025 .

Stanberry, L.R., Thomson, M.C., James, W., 2018. "Prioritizing the needs of children in a changing climate". PLOS Medicine 15, e1002627. https://doi.org/10.1371/journal. pmed.1002627.

Stevenson, K.T., Peterson, M.N., Bradshaw, A. 2016. "How Climate Change Beliefs among U.S. Teachers Do and Do Not Translate to Students". PLOS ONE 11, e0161462. https:/ doi.org/10.1371/journal.pone.0161462.

UNICEF. 2019. "A Gathering Storm [WWW Document]". URL https://www.unicef.org/rosa/reports/gathering-storm (accessed 8.5.19).

UNICEF. 2015. "Unless we act now: The impact of climate change on children [WWW Document]". UNICEF. URL https://www.unicef. org/publications/index_86337.html (accessed 8.5.19).

Walker, G. 2012. Environmental Justice: Concepts, Evidence and Politics. London: Routledge.
Williams, S., McEwen, L.J., Quinn, N. 2017. "As the climate changes: Intergenerational action-based learning in relation to flood education". The Journal of Environmental Education 48, 154-171. https://doi.org/10.1080/00958 964.2016.1256261.

Youth and the 2030 Agenda for Sustainable Development | United Nations For Youth [WWW Document]. 2018. . United Nations Youth. URL https://www.un.org/development/desa/ youth/world-youth-report/wyr2018.html (accessed 8.5.19).

Yunita, S.A.W., Soraya, E., Maryudi, A. 2018. "'We are just cheerleaders": Youth's views on their participation in international forest-related decision-making fora". Forest Policy and Economics 88, 52-58. https://doi. org/10.1016/j.forpol.2017.12.012. 